Revista de Estudios Histórico-Jurídicos

[Sección historia del derecho canónico indiano]

XXXIX (Valparaíso, Chile, 2017)

[pp. 239 - 265]

\title{
Pedro de Reina y Maldonado y la Visita de IDOLATRÍAS: ¿DEBER DE LOS OBISPOS INDIANOS?
}

[Pedro de Reina y Maldonado and the visits against idolatry: A duty of the Bishops in the Indies?]

\author{
Macarena Cordero Fernández* \\ Universidad Adolfo Ibáñez, Chile
}

\begin{abstract}
RESUMEN
Durante los siglos XVII y XVIII en diversas diócesis andinas, dependientes de la arquidiócesis de Lima, se realizaron visitas contra las idolatrías de los indígenas, con la finalidad de poner fin a costumbres, prácticas y ritos que se alejaran de la ortodoxia católica. En tal contexto Pedro de Reina y Maldonado, canónigo de Trujillo, postuló que organizar estos tribunales itinerantes constituía un deber de los obispos americanos no contemplado en el derecho canónico universal. Así pues, lo que se estudia y analiza en el siguiente artículo es si efectivamente la organización de las visitas de idolatrías constituyó una obligación episcopal, y por tanto del derecho canónico indiano, presentado y formulado por un ambicioso sacerdote,
\end{abstract}

\begin{abstract}
During the $17^{\text {th }}$ and $18^{\text {th }}$ Centuries, several dioceses of the Andean plateau subject to the Archdiocese of Lima were visited to eradicate idolatry among the indigenous population to end the traditions, practices and rites not related to the orthodox Catholic doctrine. In this context, Pedro de Reina Maldonado, canon from Trujillo, stated that the American bishops had the duty, which was not laid down in the Universal Canon Law, to organize these mobile courts. Hence, this article studies and analyses if the organization of these visits against idolatry was actually an Episcopal obligation-and, consequently, of the Canon Law of the Indies- presented and stated by an ambitious priest born in Lima
\end{abstract}

RECIBIDO el 24 de noviembre de 2016 y ACEPTADO el 26 de mayo de 2017

* Profesora del Departamento de Historia, Universidad Adolfo Ibáñez. Este artículo forma parte del proyecto "Religiosidad indígena e idolatrías en Hispanoamérica colonial". UNAM. PAPIIT IG400115. Dirección electrónica: maria.cordero@uai.cl 
natural de Lima, que aspiraba a ascender en la jerarquía eclesiástica.

Palabras clave

Visitas de idolatrías - Deberes episcopales americanos - Carrera eclesiástica - Agenciamiento. who wanted to ascend in the ecclesiastical hierarchy.

\section{KEYwORDS}

Visits against idolatry - American Episcopal obligations - ecclesiastical career - arrangements

\section{INTRODUCCIÓN}

Durante los siglos XVII y XVIII, en diversos territorios de la arquidiócesis limeña se llevaron adelante las visitas de idolatrías, cuyo fin principal consistió en extirpar las prácticas heterodoxas de los indígenas bautizados sometiéndolos a procesos judiciales. Séquitos integrados por jueces, fiscales, notarios, intérpretes y verdugos, entre otros, recorrían las zonas rurales del virreinato peruano en busca de los indios apóstatas e idólatras. Tales tribunales eran organizados por los obispos, quienes delegaban sus facultades jurisdiccionales en los visitadores. Respecto de ello, cabe la pregunta: ¿los obispos de las diócesis andinas estaban obligados a organizar las visitas de idolatrías, o era un sistema que podían activar voluntariamente en caso de tener noticias de la existencia de un foco heterodoxo?

Más aún, si efectivamente se trató de un deber de los obispos, este hecho implica establecer que en los Andes hubo obligaciones especiales para ellos, en razón de que el contexto era radicalmente distinto al europeo, lo que significó co-crear y redefinir el derecho eclesiástico. En buenas cuentas, así como la visita ad limina tuvo una regulación diversa en los distintos territorios del imperio español, de igual forma podríamos sostener que hubo otras imposiciones y facultades no contempladas en el derecho canónico universal, y que tienen solo exclusiva relación con las diócesis americanas, entre ellas el deber de realizar visitas de idolatrías.

La importancia de la presente investigación radica precisamente en la exploración del sello identitario, a veces casi imperceptible, que se manifiesta en los concilios provinciales, sínodos, jurisprudencia y doctrina canónica emanada de los espacios americanos, de los cuales se rescatan estos deberes especiales.

Postulo, entonces, que los obispos andinos tuvieron como tarea el recurrir a las visitas de idolatrías y activarlas en caso de tener conocimiento de que en alguna localidad los indígenas eran apóstatas o continuaban celebrando sus viejos ritos. Para ello, me baso en la obra: "Norte claro del perfecto prelado en su pastoral de gobierno. Tratase en el de la economía y policía domestica de su casa y acertada elección de sus ministros con disposición de las visitas de su catedral e iglesias", publicada en 1653, y escrito por Pedro de Reina y Maldonado, canónigo de la catedral de

1 Reina y Maldonado, Pedro, Norte claro del perfecto prelado en su pastoral de gobierno. Tratase en el de la economía y policía domestica de su casa y acertada elección de sus ministros con disposición de las visitas de su catedral e iglesias (Madrid, Melchor Sánchez, 1653). 
Trujillo, contemporáneo a los hechos descritos y que estimó conveniente registrar y manifestar detalladamente las diversas exigencias de los obispos, especialmente en América. ¿Cuáles fueron los motivos que llevaron al sacerdote a escribir esta obra? ¿Qué importancia revistió para él y sus contemporáneos la publicación de este libro y qué repercusiones tuvo? Son algunas de las preguntas que surgen al aproximarse al sacerdote peruano y a esta destacada publicación, que desde ya podemos considerar como parte de una estrategia elaborada por el canónigo para ascender en su carrera eclesiástica.

\section{EVANGELIZACIÓN Y PERVIVENCIA DE LAS IDOLATRÍAS EN} LOS ANDES

Desde el inicio del proceso de la conquista y colonización del Nuevo Mundo, la Corona y la Iglesia ${ }^{2}$ tuvieron por misión la evangelización de los indígenas, como también realizar todo aquello que contribuyera a "que conservaran la fe en sus corazones" y llevasen un estilo de vida "civilizado" 3 . Tal política se intensificó bajo el reinado de Felipe II $^{4}$, época que coincidió con la celebración del Concilio de Trento, el que tuvo por finalidad contrarrestar el protestantismo y otras herejías derivadas de él.

Con todo, y pese a los años de colonización y evangelización de los indígenas, lo cierto es que a finales del siglo XVI el sistema impuesto en América para aculturar a los indios carecía de un proyecto unitario ${ }^{5}$, cuestión que influyó sin duda en que no se pudieran eliminar del todo los ritos precolombinos -los que persistieron larvada o abiertamente-, y que a juicio de los españoles constituían

${ }^{2}$ La estructura institucional del imperio español descansa en el derecho de patronato, lo que significó que la "Iglesia Católica y los representantes del monarca en las Indias actuaron de consuno en la estructura del poder estatal", cuestión que explica -en parte- por qué ambas instituciones tienen por finalidad la unidad de la fe. Traslosheros, Jorge, Armonía de voluntades. Potestades eclesiásticas y secular en la Nueva España del siglo XVII, a propósito de San Miguel el Grande, en Iberoamericana, Nueva Época, 1/3 (2001), pp. 41-60.

${ }^{3}$ En efecto, el jesuita Acosta estima que a los indígenas se los debía “[...] atraer, pues, a estos hombres salvajes y enferiecidos a género de la vida humana, y acomodarlos al trato civil y político, éste debe ser el primer cuidado del gobernante. Será en vano enseñar lo divino y celestial a quien se ve que ni siquiera cuida ni comprende lo humano". En, AcosTA, Joseph de, De procuranda indorum salute (Madrid, Consejo Superior de Investigaciones Científicas, 1984), II, pp. 3-19.

${ }^{4}$ Felipe II ordenó: "Según la obligación y cargo con que somos señores de las Indias y estados del mar océano ninguna cosa deseamos mas que la publicación y ampliación de la ley evangélica y la conversión de los indios a nuestra santa fe católica [...] sobre todo se desvelen y ocupen con todas sus fuerzas y entendimiento en los otros medios necesarios y convenientes para que los indios y naturales de aquellas partes se conviertan y conserven en el conocimiento de Dios nuestro Señor [...]", en Nueva Ordenanza para el Consejo, Felipe II, El Pardo, 24 de septiembre de 1571. Cap. 5, en Anuarios de Estudios Americanos, 14 (1957).

5 Para más detalles de los sistemas de evangelización, ver: EsTENSSORO FuCHS, Juan Carlos "Descubriendo los poderes de la palabra: funciones de la prédica en la evangelización, en Ramos, Gabriela, La venida del Reino (Cusco, Centro de Estudios Regionales Andinos Bartolomé de las Casas, 1994), pp. 75 ss. 
i d o l a t r í a s. De tal modo, quedaba en evidencia que la evangelización llevada adelante hasta entonces había sido insustancial y vana.

Paralelamente, en Lima se celebraba el tercer concilio, que r e c i b í a lo normado en Trento, aunque $\mathrm{r}$ a d u c i d o a las circunstancias locales del virreinato, que buscaba lograr la unidad y ortodoxia católica en los Andes. La realización del concilio se producía en momentos en que Cristóbal de Albornoz descubría el movimiento mesiánico del Taki Onquoy -del quechua "enfermedad del canto"-, circunstancia local que contribuyó a establecer disposiciones especiales que pusiesen fin a las religiones andinas o a la idolatría colonial. En efecto, el movimiento indígena pretendía destruir el Dios cristiano, para restituir las huacas -las que eran entendidas por los españoles como divinidades precolombinas- lo que conllevaría el desmoronamiento del poder político del conquistador hispano en el espacio peruano $^{6}$. Sin embargo, este fue pesquisado por el cura doctrinero Cristóbal de Albornoz, quien dio noticia al virrey Toledo, el que respaldó lo descubierto y destruido durante la visita del doctrinero.

Así, paulatinamente la Iglesia católica en los Andes dio inicio a una política de endurecimiento frente a prácticas culturales, rituales o religiosas que se consideraron heterodoxas, lo que implicó que el sincretismo que se había gestado durante los primeros años de la conquista y colonización fuera visto como una amenaza para la ortodoxia ${ }^{7}$. En vastos territorios se entendió que la religión andina ${ }^{8}$ había persistido, aunque transformada, resignificada o recreada, fuese por el

\footnotetext{
${ }^{6}$ Para más detalles, ver AlBornoz, Cristóbal, Instrucción para descubrir todas las guacas del Perú y sus camayos y haciendas, en Urbano, Henrique; Duviols, Pierre (eds.), Molina y Albornoz. Fábula y mito de los Incas (Madrid, Historia 18, 1989); Poma De Ayala, Felipe Guaman, Nueva crónica y buen gobierno. Traducción, prólogo, notas y cronología Franklin Pease (Caracas, Biblioteca Ayacucho, 1980); Regalado De Hurtado, Liliana, Religión y evangelización en Vilcabamba 1572-1602 (Lima, Pontificia Universidad Católica del Perú, 1992).

${ }^{7}$ En el mismo sentido para el mundo novohispano, GreENLEAF, Richard. La Inquisición en Nueva España. Siglo XVI (México, Fondo de Cultura Económica, 1985), p.12.

${ }^{8}$ Entendemos por religión andina aquella que surge del choque entre la cultura indígena y la europea, cuestión que conllevó la reinterpretación de las religiosidades indígenas con la incorporación de elementos cristianos. Es decir, se produjo un proceso de resignificación, que, como tal, se alejó de la ortodoxia urgiendo su represión. Cordero Fernández, Macarena. Institucionalizar y desarraigar. Las visitas de idolatrías en la diócesis de Lima, siglo XVII (Lima, Instituto Riva Agüero, Pontificia Universidad Católica de Lima, Universidad Adolfo Ibáńez, 2016). Duviols, Pierre. La lutte contre les religions autochtones dans le Pérou colonial (Lima, Travaux de L'Institut Français d'Etudes Andines. L'Institut Français d'Etudes Andines, 1971); ÉL MISMO, Cultura andina y represión: procesos y visitas de idolatrías, Cajatambo siglo XVII (Cusco, Centro de Estudios Rurales Andinos Bartolomé de las Casas, 1986); Él mismo, Albornoz y el espacio ritual andino prehispánico, en Revista Andina, 2/1 (Cusco, 1984); Él mIsmo, Procesos y visitas de idolatría. Cajatambo siglo XVII (Lima, Pontificia Universidad Católica del Perú, 2003); GRIfFITHS, Nicholas, La cruz y la rerpiente (Lima, Pontificia Universidad Católica del Perú, 1998); Mills, Kenneth, Idolatry and its enemies. Colonial Andean religion and extirpation, 1640-1750 (New Jersey, Universidad de Princeton, 1997); GareIs, Iris, La metamorfosis de los dioses: cambio cultural en las sociedades andinas, en Anthropologica, 9 (2012), pp. 245-257. Para el caso de Atacama, Hidalgo, Jorge ha realizado una extensa investigación al respecto: Historia Andina en Chile (Santiago, Editorial Universitaria, 2004). Él mIsmo, Redes eclesiásticas, procesos de extirpación de idolatrías y cultos andinos coloniales en Atacama. Siglos XVII y XVIII,
} 
influjo de la religión católica o bien por la necesidad de contrarrestar la religión de los españoles. A ello sumemos que aquellos indígenas que se habían convertido al catolicismo se encontraban en un proceso de adaptación, en cuanto debían incorporar la doctrina de la Iglesia a su imaginario, lo que implicaba un nuevo proceso de reinterpretación, que se veía interferido por la lejanía de las ciudades o espacios en los que el catolicismo estaba radicado.

En tales circunstancias, la Iglesia resolvió destruir los falsos ídolos, reconquistar a los indígenas y reintegrarlos a las filas del $\mathrm{c} r$ e d o v e r d a d e r o . La unidad de la fe se convertía en el primer objetivo de los obispos en sus diócesis a comienzos del siglo XVII.

La estrategia en la diócesis limeña tuvo una etapa tendiente a reforzar la labor apostólica, que se tradujo en propiciar la aculturación y transformación del modo en que los indígenas aprehendían la realidad, pues el peligro constante e inmanente se encontraba precisamente allí, donde pervivía o rebrotaba la idolatría, para lo cual se acordó reforzar la evangelización?

Con todo, se consideró fundamental complementar la evangelización de los indígenas con la destrucción material de ídolos y de aquellas prácticas que la Iglesia consideraba heterodoxas o idolátricas, y también se promovió la represión hacia

en Estudios Atacameños, 42 (2011), pp. 113-152. Ver también las investigaciones de CASTRO, Victoria, Un proceso de extirpación de idolatrías en Atacama, siglo XVII, en RAMOs y URBANO, Catolicismo y extirpación de idolatrías. Siglos XVI-XVIII (Cusco, Centro de Estudios Regionales Andinos Bartolomé de las Casas. Cuadernos para la evangelización en América Latina no 5,1993), pp. 347-366; y Los MISMOS, De ídolos y Santos. Evangelización y religión andina en los Andes del sur. (Santiago, Fondo de Publicaciones Americanistas Universidad de Chile, Centro de Investigaciones Diego Barros Arana, 2009).

9 Se debe tener presente que el proceso de evangelización a los indígenas americanos contó con etapas diversas. Asimismo, con estrategias definidas según los espacios que se incorporaban a la cristiandad. En efecto, durante los primeros años de la conquista, los modos de evangelizar a la población americana variaron respecto a lo que aconteció a finales del siglo XVI. A modo de ejemplo, durante las primeras décadas del siglo XVI, el plan fue la eliminación de ídolos y el bautizo de miles de indígenas, aunque no hubo tiempo para profundizar los procesos. SuBIRATS, Eduardo, El continente vacio (México, Editorial Siglo XXI, 1994), pp. 108-109; EsTENsSOro, Juan Carlos, Descubriendo los poderes de la palabra: funciones en la prédica en la evangelización, en Ramos, Gabriela, La venida del Reino, cit. (n. 5), p. 75. Situación que varió a finales de la misma centuria al quedar en evidencia la superficialidad de una primera evangelización y el rebrote de prácticas religiosas precolombinas, acontecimiento que exigió establecer nuevos derroteros que profundizaran en el proceso no sólo de conversión, sino además de conservación de esa fe entre la población americana. El reforzamiento se realizó mediante la intensificación de la doctrina, la que se debía enseñar los días miércoles y viernes, y la prédica todos los domingos y fiestas de guardar, la que debía ser impartida por curas que estuviesen certificados en el entendimiento de lenguas andinas. "Que todos los clérigos que se opusieren a doctrina o los religiosos que se presentaren a ella fuera del examen ordinario, para ver si saben la lengua, prediquen con ella públicamente, señalándoles el día antes puntos para el sermón”. ArriagA, Pablo de, Extirpación de la idolatría en el Perú. Estudio preliminar y notas de Urbano, Henrique (Cusco, Centro de Estudios Regionales Andinos Bartolomé de las Casas, 1999), p. 106. Más aún, se recomendaba a los doctrineros anotar sus sermones y mostrarlos al visitador ordinario para que este les sugiriese cambios, si era el caso. Para aquellos que no estuviesen seguros de cómo hacer las prédicas, durante el siglo XVII se publicó una serie de sermonarios y manuales de confesión, dirigidos especialmente a la población indígena, cuyo contenido decía relación directa con las idolatrías. 
los dogmatizadores y hechiceros, para lo cual se crearon e institucionalizaron 1 a s vis itas de idolatrías, institución propia del derecho canónico local, que tenía atribuciones y facultades de orden judicial, moral y religioso, cuya finalidad era someter a procesos judiciales a los sospechosos de idolatrías, reconducirlos a la ortodoxia católica y asegurar que el comportamiento de los indios fuese conforme al derecho natural ${ }^{10}$.

Es importante consignar que la visita de idolatría es una visita diversa de la pastoral. En efecto, el concilio de Trento ordenó especialmente a los patriarcas, primados, metropolitanos y obispos realizar visitas pastorales - por sí o por medio de sus vicarios- al interior de sus diócesis, las que tenían por principal finalidad examinar el estado en que se encontraba el obispado, esto es, fiscalizar el régimen parroquial, como también, la fe de la feligresía, reforzar la doctrina, corregir errores y falsas creencias. Así pues, durante éste tipo de visita el obispo podía observar el estado material de las parroquias, recibir denuncias contra los doctrineros, o prácticas reñidas con la moral y doctrina cristiana de la población, entre otras tantas facultades ${ }^{11}$. No obstante, y pese a que durante la visita el obispo podía recibir tales denuncias, lo cierto es no tenían autoridad para corregir y castigar mediante un proceso judicial a la población, pues carecían de jurisdicción contenciosa ${ }^{12}$.

La visita de idolatría, en cambio, contó expresamente con facultad de jurisdicción, pudiendo someter a proceso judicial canónico a los indígenas apóstatas. Más aún, las visitas de idolatrías emprendidas durante el siglo XVII y comienzos de la siguiente centuria en las diócesis de Lima, Trujillo ${ }^{13}$ y Charcas $^{14}$ se constituyeron ante la imposibilidad de que actuara el Santo Oficio ${ }^{15}$, el que careció

${ }^{10}$ Para más detalles, ver Cordero Fernández, Macarena. cit. (n. 8). Duviols, Pierre, La Lutte contre, cit (n. 8); García Cabrera, Juan Carlos. Ofensas contra Dios (Cusco, Centro de Estudios Bartolomé de las Casas, 1994); Mills, Kenneth, cit. (n. 8); Griffith, Nicholas, cit. (n. 8).

11 Para más detalles ver Conc. Trid., sess. 24 c. 3, en Los Sacro Santos Ecuménicos Concilios de Trento y Vaticano. Traducción del presbítero Anastasio Machuca Diez (Madrid, Librería Católica de Gregorio del Amo, 1903).

${ }^{12}$ Cap. Romana I, de censibus No6, se encuentra en Liber Sextus, Lib. III, Tit. XX, De censibus, exactionibus et procurationibus, Cap. I, que contiene una decretal del Papa Inocencio IV, conocida por las palabras iniciales Romana Ecclesia.

13 El Archivo Arzobispal de Trujillo contiene 28 legajos de procesos por idolatrías correspondientes a los siglos XVIII y XIX, los que se habrían desarrollado en las zonas rurales mediante las visitas de idolatrías según el modelo esbozado en el Manual de Arriaga, Sínodo de Lima de 1613, y especialmente la carta pastoral de Pedro de Villagómez, texto de amplia circulación virreinal, y complementado por el libro VI de la obra de Reina y Maldonado. Los legajos por procesos de idolatrías se encuentran en el Archivo Arzobispal de Trujillo. Sección Hechicerías. Veintitrés de ellos han sido transcritos y publicados en LARCO, Laura, Más allá de los encantos. Documentos históricos y etnografía contemporánea sobre extirpación de idolatrías en Trujillo. Siglos XVIII-XX. (Lima, Instituto Francés de Estudios Andinos, Fondo editorial Universidad de San Marcos, 2008).

${ }^{14}$ Los estudios desarrollados por Victoria Castro para Atacama dan cuenta del mismo sistema extirpador, De ídolos y santos, cit. (n. 8).

15 Sabido es que los indios quedaron excluidos de la jurisdicción del Santo Oficio, probablemente luego de los hechos acontecidos en el obispado de Zumárraga en Nueva España en el siglo XVI, período en el que se condenó a muerte al cacique don Carlos por actuaciones 
de jurisdicción sobre los indios por expresa resolución de la Corona. Así, en el espacio andino surgió esta institución de carácter judicial ${ }^{16}$, correctivo y misional, mediante la cual un séquito ad hoc-pues se forma solo cuando se tiene noticias de la existencia de un foco heterodoxo- recorrería de manera itinerante las zonas rurales, sometiendo a proceso a quienes correspondiese, y aplicando castigos a los culpables. ${ }^{17}$

En adelante la iglesia andina contó con un dispositivo judicial que podía controlar la religiosidad y los comportamientos de la población cada vez que fuese necesario ${ }^{18}$, sistema que se consolidó de acuerdo con lo regulado especialmente en

idolátricas GreEnLEAF, Richard, cit. (n. 7) y Zumárraga y la Inquisición mexicana, 1536-1543 (México, Fondo de Cultura Económica, 1985).

16 Para la organización de las visitas de idolatrías se recurrió al derecho canónico, a los sínodos y concilios, al derecho inquisitorial, a los pareceres de los jesuitas que vivían y recorrían el espacio andino, entre otras fuentes. El procedimiento aplicado fue básicamente el procedimiento inquisitivo, que por lo demás le dio el nombre a la inquisición aunque traducido a la realidad local peruana, lo que implicó que se viera reinterpretado a partir del estatuto jurídico indígena que concedía una serie de privilegios. Ver Cordero, Macarena, cit. (n. 8); Duve, Thomas, Los privilegios de los indios. ¿Derecho Local?, en Torres Aguilar, Manuel (coord.), Actas del $X V$ Congreso del Instituto Internacional de Historia del derecho indiano, Córdoba, del 19-24 de septiembre 2005 (Córdoba, Diputación de Córdoba, Universidad de Córdoba), I, pp. 111-130.

${ }^{17}$ Con todo, hay un sector de la historiografía jurídica canónica que considera que el obispo, en el ejercicio de la visita pastoral, podía ejercer jurisdicción contenciosa y por ende someter a proceso a los indígenas, según Sesión XXIV, Cap. 10 del Concilio de Trento. Y por tanto la visita de idolatrías sería parte de la pastoral, Guibovich, Pedro, Visitas eclesiásticas y extirpación de la idolatría en la diócesis de Lima en la segunda mitad del siglo XVII, en ZabalLA (coord.), Los indios, el derecho canónico y la justicia eclesiástica en la América virreinal (Madrid, Iberoamericana/Vervuert. 2011), pp. 177-209. Sin embargo, la doctrina jurídica de la época estimó que ello no era posible, entre ellos Fagnano, Solórzano Pereira y el canónigo de Trujillo Pedro de Reina y Maldonado. Ello es relevante, toda vez que la doctrina jurídica era una de las fuentes jurídicas y contaba con la misma jerarquía que una ley durante el Antiguo Régimen. A su vez, es necesario tener presente la costumbre, que era otra de las fuentes del derecho, tenía igual jerarquía que la ley. Así pues, al observar las visitas pastorales realizadas en Chile o en el Cusco durante el período colonial, es posible verificar que en ellas los obispos detectaron la existencia de conductas contrarias a la fe cristiana. Con todo, no sometieron a proceso a los culpables durante el transcurso de la visita, sino que solicitaron que los idólatras abjuraran y destruyeran materialmente los ídolos. O bien dejaron constancia en sus visitas de lo que habían observado, para luego en sus sedes episcopales determinar el camino a seguir, siendo una de las posibilidades la de juzgar en la sede obispal. Ejemplo de ello es la visita realizada por el obispo del Cusco Manuel de Mollinedo y Angulo en la localidad de Sicuani, en la que "Predicose con el aprovechamiento del evangelio, doctrina cristiana y abjuramiento de la idolatría [...]". Sin embargo, la visita no hace mención de que se hubiese sometido a proceso a los indios por idólatras. Visita que el doctor Manuel de Mollinedo y Angulo, obispo del Cusco, del Consejo del rey Nuestro Señor, se hiso en el año 1674, en Guibovich, Pedro y Wuffarden, Luis Eduardo, Sociedad y gobierno episcopal. Las visitas del obispo Manuel de Mollinedo y Angulo 1674-1687 (Lima, Instituto Riva Agüero, Instituto Francés de Estudios Andinos, 2008), p. 74. Para más detalles, ver CoRDERO FERNÁNDEZ, Macarena, cit. (n. 8), p.177 y ss.

${ }^{18}$ No es novedad que la visita de idolatrías constituya una forma de control social. Lo anterior, porque la v is i t a en general fue creada por el derecho canónico como un instrumento de fiscalización, de vigilancia que ejercía el obispo en su diócesis. LE BRAS, George, Les origines canoniques di droit administratif, en L'evolution du droit public, études offertes a Achille mestre, 
el Sínodo de Lima de $1613^{19}$, y en el Manual de extirpación de Arriaga ${ }^{20}$, orden normativo que se actualizó mediante la carta pastoral de Villagómez en $1649^{21}$.

Las visitas de idolatrías fueron organizadas por los obispos cada vez que hubo noticias de la existencia de un foco heterodoxo. Charcas, Trujillo y Lima fueron los espacios protagonistas de la extirpación de idolatrías mediante este sistema que se institucionalizó a lo largo del siglo XVII y del que dio cuenta largamente Pedro de Reina y Maldonado.

\section{LAS Visitas De idolatrías en Pedro de Reina Y MaLdonAdo}

Pedro de Reina y Maldonado fue un sacerdote peruano nacido en Lima en 1601, hijo de Francisco Martín Reina -quien sirvió en las fortalezas del Callao-y María Maldonado. Según lo expresado por sus contemporáneos: “[...] Dixo que este testigo conoce al d.ho Doctor don pedro de rreyna mal donado de quarenta años a esta parte de trato y comunicassion y an si mismo conocio trato y comunico a sus padres y ermanos los quales son y an ssido gente mui honrada y birtuossa christianos biexos linpios de toda mala rrasa y macula y que se ocuparon en obras pias siendo bienechor desta rrepublica como lo a visto ser y pasar este testigo y esto rresponde $=y$ bio que el susso d.ho desde sus primeros años se ocupa en sus estudios con todo cuydado y bigilancia con aprobechamiento y lusimiento de sus letrados y mediante ellas tiene entera noticia este tt.o y es publico e notorio que se dotoro el ssuso dicho $=Y$ sienpre vibido con toda virtud y exemplo modestia y conpostura de su persona con que tiene ganada y asi querida mui buena opinion y fama y esta bien rrecevido y estimado de todos sin que xamas se aya oydo y entendido quexa alguna de su perssona antes mucha alabanza de su ajustado prosseder como lo a visto assi sser y passar este testigo y es pu.co e notorio sin aver oydo ni entendido cossa en contrario $[. .]^{22}$.

La información rendida por Diego de Córdoba, canónigo de Lima, enfatiza en el conocimiento que posee de la familia y de los valores de los Reina y Maldonado. En el contexto contrarreformista que se vivía en el siglo XVII era muy significativo formar parte de una familia de cristianos viejos, "limpios de toda mala raza y mácula”. Más aún, en espacios tan distantes de la Corona y con controles sociales más laxos que los peninsulares ${ }^{23}$, el contar con un sacerdote con estas caracterís-

(Paris, Sirey, 1956), p. 14. En efecto, mediante la v is i t a p a s t o r a 1 los obispos revisaban el estado material de las iglesias, de las cosas sagradas, entre otras. Y además el estado de la fe de los fieles. Mediante la visita de idolatrías, los obispos andinos pudieron someter a proceso judicial a los idólatras, constituyéndose como un tribunal ad hoc. Ver Cordero Fernández, Macarena, cit. (n. 8).

19 Sínodo de 1613, celebrado durante el obispado de Bartolomé Lobo Guerrero.

${ }^{20}$ Arriaga, Pablo de cit. (n. 9).

${ }^{21}$ Villagómez, Pedro de, Carta pastoral de exhortación e instrucción acerca de las idolatrías de los indios del arzobispado de Lima. 1649.

22 Archivo General de Indias (en adelante AGI), Lima, 240, № 6, Información Pedro de Reina y Maldonado. 1647, f. 14, declaración del canónigo de Lima, Diego de Córdoba.

23 En relación con las formas de control social en el período colonial, ver Cordero Fernández, Macarena, Precariedad del proyecto disciplinador de la Corona e Iglesia en el siglo 
ticas -modesto, compuesto, de buena fama y limpieza de sangre-era una particularidad ${ }^{24}$ destacable, pues la escasez de funcionarios eclesiásticos y monárquicos idóneos para los diversos cargos constituyó una dificultad que debía de resolverse con mayor o menor énfasis según la diócesis en cuestión.

Quienes testificaron a favor de Pedro de Reina y Maldonado destacaron sus conocimientos en derecho y teología. En efecto, el canónigo de Trujillo se había licenciado y doctorado en teología en la Universidad de Sevilla ${ }^{25}$, además de ser confesor y predicador en el arzobispado de Toledo. Mientras estudiaba, impartió clases de gramática en el seminario de Lima ${ }^{26}$. Perteneció a la Compañía de Jesús, de la que fue expulsado, aunque "[...] por cosas que no fueron escandalosas ni tales que le hagan inhábiles" 27 . Una vez expulsado, al parecer ingresó a la orden de los franciscanos. Profesor de teología en la Universidad de San Marcos ${ }^{28}$, en 1622 fue ministro del obispo de Lima, notario y secretario de su cámara apostólica. A partir de 1624 es canónigo de Trujillo, luego provisor, vicario y comisario apostólico de aquella diócesis. En tal calidad, fue enviado en 1645 desde Trujillo como delegado a Lima para disuadir al padre Pedro Ortega y Sotomayor de ingresar al claustro de los jesuitas, y convencerlo de aceptar el nombramiento para obispo de Trujillo, misión que realizó con éxito, puesto que Ortega recibió la consagración papal, convirtiéndose en obispo de Trujillo, y luego de Arequipa y $\mathrm{Cusco}^{29}$.

Además de su destreza y capacidad de persuasión, destacan sus habilidades y conocimientos en letras; en efecto: "[...] Maldonado canonigo mas antiguo de la Santa yglessia catredal desta d.ha ciudad comisario apostolico subdelegado de la Santa crussada provisor y vicario general deste obispado fue electo y nombrado por tal provissor y bicario general por boto de todos los señores dean y cavildo en la sede bacante del Yll.mo Señor dotor don diego de Montoya y Mendoza de buena memoria como consta del cavildo que se hizo en beinte y uno del mes de marzo del año de mill y seiscientos y quarenta a foxas ducientas y treinta y quatro de su libro con general

XVIII: las doctrinas periféricas de la diócesis de Santiago de Chile, en GAUNE, Rafael; UNDURRAGA, V., Formas de controly disciplinamiento. Chile, América y Europa, siglos XVI-XIX (Santiago, Uqbar Editores, 2015), pp. 143-166; LA MISMA, Inquisición en Chile y control social, en SÁNCHEZ, Marcial (comp.), Historia de la Iglesia en Chile, (Santiago, Ed. Universitaria, 2010), II, pp. 163-193.

${ }_{24}$ Un problema extendido en el período colonial fue el no contar con suficientes sacerdotes y laicos que tuvieran limpieza de sangre, cuestión que implicó, por ejemplo, para el caso de Chile, que las vacantes para familiares de la Inquisición no se llenaran y fueran suplidas, interinamente, con sujetos que no cumplían con los requisitos para serlo. Para más detalles, ver Archivo Histórico de Madrid. Fondo Inquisición, Lima, Libro 1040.

25 AGI, Lima, 240, No 6. Información Pedro de Reina y Maldonado. 1647, f. 31v, declaración de Francisco Calvo de Sandoval, racionero de la Iglesia.

${ }^{26}$ Pardo Sandoval, Teresa, Un impreso peruano desconocido, en Boletín del Instituto Riva Agüero, 15 (1988), pp. 155-162 esp. p. 158.

27 Medina, Toribio, Biblioteca Hispanoamericana (1493-1810) (Santiago, Imprenta del Autor, 1898) II. pp. 213, 216, 491, 500 y 502. AGI. Lima 240, N 6. 1647. Informaciones: Pedro de Reyna Maldonado, cit.

28 AGI. Lima 240, N 6. 1647. Informaciones: Pedro de Reyna Maldonado, f. 41v, declaración de José de los Reyes Quinteros, abogado de la audiencia de Lima, visitador de Trujillo.

${ }^{29}$ Vargas Ugarte, Rubén, Historia de la Iglesia en el Perú (Burgos, Imprenta de Aldecoa, 1956). III, p. 23. 
aplausso y aclamacion; del clero, el qual d.ho oficio, continuo, hasta el dia que el Yll. mo señor dotor don pedro de ortega ssotomayor obispo desta ciudad del consexode su magestad lo elixio y nombro por su probissor y vicario general que actualmente le esta exerciendo con grande aceptación del cavildo desta santa yglessia, clero y vecinos desta ciundad por sus grandes partes de letras birtud y gobierno y para que de ello conste de pedimento del d.ho señor canonigo comissario provissor y bicario general diel presente en la d.ha ciudad de Truxillo del piru enbeinte. ${ }^{30}$

En su rol de subdelegado de la Santa Cruzada, los que lo conocieron señalaron: "[...] obligaciones de su oficio que mediante su bigilancia y cuidado a tenido los buenos efetos que sse an experimentado en la cobranza y espedicion de las bulas de la santa cruzada y enbios de plata que sse an fecho a su magestad con aprovacion del tribunal subdelegado general de La santa crussada que rresideen esta ciudad de los rreyes [...] '31.

A su vez, fue visitador del gobierno provincial, gobernador provincial y vicario general de su obispado. Quienes se relacionaron con él estimaron que Pedro de Reina y Maldonado era: "[...] persona tan ¿? e ynteligente en los negocios $y$ correspondencias que tiene a su cargo en todo este rreyno que el d.ho dotor don pedro de rreyna Maldonado a exerssido y exersse el dicho oficio con toda aprobaciode sus perlados linpiesa y rretitud como tan buen juez assiendo justicia a las partes sin omission y quexa alguna por aver prossedidoy prosseder con toda ajustamiento [...] ${ }^{\text {'32. }}$. Más aún, diversos informes coinciden en que se trata de un canónigo querido y respetado por los vecinos y la feligresía: “[...] en toda aquella rrepublica esta mui bien rrecevido querido y estimado de todos assi por sus muchaspartes como por su virttud y exemplo que da a todos con su bida e costumbres como tan buen sacerdote sin aver bisto oydo ni entendido este testigo cossa en contrario por que si lo fuera lo supiera y ubiera entendido por ser como es natural becino y asendado en la d.ha ciudad de Truxillo donde tiene su asistencia [... ${ }^{\text {'33 }}$.

Todos los atributos que se le adjudican a Reina y Maldonado explican por qué sus contemporáneos consideraron que contaba con los: "[...] meritos del d.ho dotor don pedro de rreyna Maldonado es digno y meressedor de mayores acenssos y que su magestad se sirva de aser la mersed de pressentarle a una canongia o dignidad desta santa yglessia de los rreyes de quedara mui buena quenta asegurando la rreal conciencia de su magestad y estaba mui bien enpleado en su persona [... $]^{34}$.

Así pues, tal como ya se ha referido, por más de veinte años se desempeñó como canónigo de Trujillo, sin haber recibido otras mercedes y prebendas, por lo que para quienes rindieron información de méritos de Reina y Maldonado, ya era tiempo de que mudara de estado. En tal sentido el canónigo de Lima Sebastián Loyola Bustamante indicó: "[...] su buena capassidad letras e yngenio assi

30 AGI, Lima, 240, No 6. Información Pedro de Reina y Maldonado. 1647, f. 8.

31 Ibíd., f. 16, declaración del canónigo de Lima, Diego de Córdoba. En sentido similar, Pedro Cabero del Nao, f. 22v. y Roque de Cubiate, vecino de Trujillo y tesorero de la Santa Cruzada, f. 35.

32 Ibíd., f. 16, declaración del canónigo de Lima, Diego de Córdoba.

33 Ibíd., f. 22, declaración del presbítero de Trujillo Pedro Cabero del Nao. En sentido similar, Francisco Niño de las Quentas, Caballero de la Orden de Santiago, f. 38.

${ }^{34}$ Ibíd., f. 16, declaración del canónigo de Lima, Diego de Córdoba. 
en las escuelas y claustro desta rreal uniberssidad como en el pulpito pedricando el santo evangelio con toda aprobación por su buen celo y enseñansa y conossido espiritu y talento con que tiene adquerida mui buena opinión y fama lo que ai se conprueva assimesmo con su virtud y exemplo con que tiene adqueridas las boluntades y esta mui bien rrecevido y estimado assi en la d.ha ciudad de Truxillo como en elta rrepublica como el publico e notorio y lo a visst sser y passar asi este testigo y save y es cossa mui sierta y verdadera que el sussod.ho demas de beinte años desta parte es tal canónigo de la Santa yglessia de la d.ha ciudad de Truxillo sin que aya tenido otro Aumento de dignidad siendo como es tan benemérito y de tantas partes y suficiencia [... ${ }^{\text {'35. }}$.

Por su parte el Marqués de Mancera señalaba de Reina Maldonado que al tiempo de haber sido provisor en sede vacante, "la ha gobernado con mucha prudencia y ejemplo"36. Destacaba, además, el hecho de que en Madrid había publicado los siguientes libros: De los sacramentos y ceremonias de la misa (1623); Defensas de varias facultades de los prelados (1648); Sobre el vasallo ideal (1623); Apología de la iglesia de Trujillo (1647) ${ }^{37}$.

A lo anterior hay que agregar que Reina y Maldonado publicó en 1653, también en Madrid ${ }^{38}$, Norte claro del perfecto prelado, obra que según el Cabildo eclesiástico de Trujillo reflejaba "la experiencia del gobierno eclesiástico que ha tantos tiene a su cargo" ${ }^{39}$, constituyendo, tal vez, su obra más importante, y que, a juicio del presbítero de Trujillo Pedro Cabero, en él se muestra "^[...] grande herudicion dotrina y enseñanza en que a demostrado su gran talento y letras y lo a leydo en parte este testigo" ${ }^{40}$. El contenido de este texto se dirige especialmente a los obispos, a la forma en que deben administrar sus diócesis, y a los deberes que deben cumplir en su cargo. Para ello, el autor realiza una recreación de Trento y del III Concilio Limense, citando, además, una serie de sínodos americanos, doctrina y costumbres eclesiásticas andinas. Así, el autor actualiza los deberes y obligaciones de los prelados, como también la normativa, poniéndola en consonancia con la realidad en la que están inmersos los obispos en América, los que, las más de las veces, enfrentan los mismos problemas. Para ello, Reina y Maldonado emprende el esfuerzo de articular el ejercicio de las distintas jurisdicciones y deberes en diferentes instancias diocesanas.

Esta obra, impresa en Madrid en 1653, fue escrita a solicitud del obispo de Trujillo, Pedro de Ortega Sotomayor, electo en aquel momento para Arequipa. Pero, además, en el trasfondo de los hechos que dan origen a esta obra se puede

35 Ibíd., f. 18, declaración del canónigo de Lima, Sebastián de Loyola Bustamante. En sentido similar, capitán Juan Sánchez de Arroyo, vecino de la ciudad, f. 26.

${ }^{36}$ Carta del virrey al rey, en Medina, cit. (n. 27).

37 Comadrán RuIZ, Jorge, Los sacerdotes criollos y las prelaturas indianas durante el periodo indiano, en Missionalica Hispana. Hispana Sacra, 42/85 (1990), pp. 213-249, esp. p. 224.

${ }^{38}$ En 11, el cabildo eclesiástico de Trujillo autorizó a Pedro de Reina y Maldonado a viajar a Madrid. Pardo Sandoval, Teresa, cit. (n. 26), p. 158.

${ }^{39}$ Cit. ibíd.

${ }^{40}$ AGI, Lima, 240, No 6. Información Pedro de Reina y Maldonado. 1647, f. 24, declaración del presbítero de Trujillo Pedro Cabero del Nao. En sentido similar capitán Juan Sánchez de Arroyo, f. 26, y Roque de Cubiate, vecino de Trujillo, f. 36. Declaración de José de los Reyes Quinteros, abogado de la audiencia de Lima, visitador de Trujillo, f. 43. 
detectar una visión estratégica. Así, Reina y Maldonado redacta este libro no solo para extenderse en cuáles son los deberes de los obispos, sino también para dar cuenta de su propio conocimiento del contexto americano, de las necesidades y conflictos con la población indígena, y cómo pueden llegar a solucionarse. Dicho de otro modo, el canónigo de Trujillo busca, mediante la comprensión que tiene del espacio, población y situaciones en las que vive, llamar la atención de las altas autoridades reales y eclesiásticas, con la finalidad de lograr alguna promoción. En resumen, se trata de una obra erudita con la cual Reina y Maldonado pretende validarse ante el Consejo de Indias y demás altas autoridades imperiales. Y en los hechos, mientras concluía y daba a leer esta obra a diversas personalidades del virreinato peruano, entre ellas, por nombrar a alguna, el oidor Meneses, presentaba información de méritos, con la esperanza de ser promovido a un mejor cargo ${ }^{41}$. De alguna manera estaba realizando un autoagenciamiento ${ }^{42}$, el que tuvo resultados positivos, puesto que, al tiempo, fue nombrado canónigo de $\mathrm{Puebla}^{43}$ y luego -al final de sus días- obispo de Santiago de Cuba.

Más aún, ello se manifiesta en la presentación del libro, que estuvo a cargo de fray Gerónimo de Contreras, cuando este señala -haciendo alusión a Reina y Maldonado- que esta obra ha sido escrita por un sacerdote con vasta experiencia, pues ha sido vicario y provisor de Trujillo por muchos años. Agrega que un gran número de eruditos hombres han escrito sobre las reglas de los perfectos prelados: "[...] mas en los prelados de las Indias donde en todo es casi nuevo el gobierno, por la variedad de gentes, ninguno sino el autor, y asi pudiera muy bien dar principio de la obra" ${ }^{44}$. Dicho de otro modo, fray Contreras indica explícitamente que la realidad americana es distinta a la conocida y normada por Roma, por lo que esta obra suple un vacío en aquellas áreas que no responden a problemas, gentes o situaciones como las de Europa. Más aún, le parece oportuno que haya sido escrita por Reina y Maldonado, puesto que se trata de un sacerdote de amplia y sobrada trayectoria, amén de poseedor de un vasto conocimiento andino. Seguidamente, en la presentación del libro se hace un fuerte hincapié en la necesidad del compromiso de los prelados de reducir la gentilidad, cuestión que nos sugiere que para 1653 la existencia de herejías, idolatrías o prácticas religiosas indígenas alejadas del catolicismo está bastante extendida en el virreinato peruano.

Pues bien, el libro, organizado en dos tomos, tuvo licencia para publicación

41 Ibíd.

42 A partir de los estudios de E. Thompson o Carlos Aguirre, se forjó el concepto de agency o agencia entendiéndose como un proceso de negociación de las condiciones sociales en que se despliega públicamente una organización comunitaria-movimiento obrero, por ejemplo- o una búsqueda de libertad -negros esclavos-. Tal concepto es posible trasladarlo a personas naturales, como a Pedro de Reina y Maldonado, quien mantiene relaciones s u b a l t e r n a s con el poder real y eclesiástico, pero que las reformula a partir de las transacciones que realiza en pos de una promoción individual. Thompson, E.P., The Making of the English Working Class. (New York, Vintage Books, 1963); Aguirre, Carlos, Agentes de su propia libertad (Lima, Pontificia Universidad Católica del Perú, 1995).

43 Comadrán Ruiz, Jorge, cit. (n. 35), p. 224.

44 Contreras, Fray Gerónimo de, en Reina y Maldonado, Pedro, cit. (n. 1), fs. 2 y 2v. 
del franciscano Gerónimo de Manríquez, en 1647, quien hizo de lector ${ }^{45}$. Tiene aprobación, a su vez, de Pedro de Meneses, oidor de la audiencia de Lima -quien lo aprobó el 14 de julio de 1647-. Si bien Meneses no leyó el libro a cabalidad, indica que "[...] en lo que he visto, hallo este trabajo digno de toda estimación, por la importancia del asunto, y admirable disposición de las materias de las que trata, llenas todas de erudición, y enseñanza, y se le juzgue muy bien al autor las experiencias del gobierno eclesiástico, en que ha tantos años, que tan a toda satisfacción se ocupa"46.

Entre las censuras del libro está la realizada por Juan Solórzano y Pereira, quien para 1652 es caballero de la Orden de Santiago, y miembro del Consejo del rey. Importa destacar: "[...] y para que les sean más fáciles y suaves de obrar, llevar y practicar, les da y propone tan saludables documentos, tan prudentes advertencias, $y$ tan prevenidas formulas, e instrucciones, que descubren bien el deseo, que tiene de los aciertos, y las noticias, que en estas materias ha conseguido, no sólo por su ciencia, y erudición, que siempre en todas partes, y facultades han sido muy estimados, sino también por la experiencia de haberlas ejercitado tan loablemente en varias ocasiones por muchos años. $Y$ si en común se le deben mostrar agradecidos todos los prelados por este trabajo, es justo que con más particularidad lo hagan los de las Indias, por los muchos y graves puntos en ambos Tomos toca, concernientes a ella, $y$ especialmente en todo el segundo, dando a entender la grande atención, y vigilancia con que deben proceder en el amparo, y enseñanza de los naturales, buena elección, examen, y visitas de sus doctrinas, y cuidado en la Extirpación de idolatrías:_Para que asi estas nuevas plantas reciban mejor el riego de la fe Católica, y echen en ellas más firmes, y seguras raices, que es lo que por tantas cedulas reales, y cánones conciliares tanto se les encarga [...]" 47 .

La opinión de Solórzano es de fundamental importancia, puesto que sabemos de su indiscutible conocimiento del derecho indiano, así como de la realidad americana, especialmente la andina. Destaca en su censura el énfasis puesto en que este libro -escrito a su juicio por otro gran conocedor del derecho y de la realidad indiana- toca, advierte y aconseja a los prelados -especialmente a los indianosde sus deberes, centrándose en los que dicen relación con el tomo II, en que se regulan las particulares obligaciones que tienen con los indios, la evangelización y la extirpación de idolatrías, ésta última desarrollada extensamente en el libro VI, en la que se da cuenta del deber episcopal de realizar la visita de idolatría en caso de tener noticias de un foco idolátrico. Más aún, en los distintos capítulos en los que se subdivide la obra, Reina y Maldonado va estableciendo requisitos para la realización de la visitas, causas de la pervivencia de las idolatrías, qué se entiende por idolatrías, cuáles son las más comunes entre los indígenas, cómo detectarlas, de la lectura del edicto contra la idolatría, de la forma en que se realizan las denuncias, de cómo castigar las idolatrías, entre otros tantos acápites regulados y analizados por el canónigo en comento ${ }^{48}$. Dicho de otro modo, el gran jurista

\footnotetext{
${ }^{45}$ Manríquez, de Pedro, en Reina y Maldonado, Pedro, cit. (n. 1), f. 3

${ }^{46}$ Meneses, Pedro de, ibíd., f. 3.

47 Solórzano, Juan de, ibíd., f. 4.

${ }^{48}$ Respecto a las visitas de extirpación de idolatrías están ampliamente reguladas en REINA y Maldonado, Pedro, cit. (n. 1), II, VI, pp. 288 ss.
} 
indiano valida que la reproducción del derecho canónico en América haya debido ser resignificado y adaptado a las circunstancias culturales y sociales propias del espacio andino, recreando los deberes de los prelados, y dando origen a otros nuevos, por efecto de la conversión de la población americana, su evangelización y la destrucción de sus creencias.

Así, para quien fuera oidor de la audiencia de Lima y luego consejero de su majestad en el Consejo de Indias, constituyó una obligación de los obispos americanos organizar las visitas de idolatrías, en caso de tener conocimiento o noticia de la existencia de un foco idolátrico, lo que es de vital importancia para comprender el núcleo significativo de las visitas, puesto que para mediados del siglo XVII el sistema de extirpación estaba no solo consolidado como institución, sino que además era entendido por Solórzano y las demás autoridades reales y eclesiásticas como un deber, y por tanto su organización se volvía inexcusable. En efecto, se lee en la obra de Reina y Maldonado, y aprobada por Solórzano: "El zelo grande de los Prelados es el que debe mover a los visitadores para el acierto en la execusión de intento, que es de tan el servicio de Dios nuestro Señor, con que teniéndole con su diligencia y solicitud continua, en poco días se recorrerá el estado de las doctrinas, y lo que los indios padecen en ellas del mal de idolatrías, y por que no se puede bien acertar a conseguir el fin sin el conocimiento de los medios, demás de la instrucción general, que llenará de lo particular que en cada obispado se puede

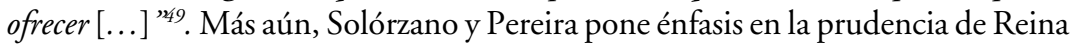
y Maldonado para mostrar cada una de las instituciones eclesiásticas mediante formulaciones acertadas gracias a sus conocimientos, erudición y la experiencia de haber vivido y trabajado en los Andes.

La censura realizada por el respetado jurista Solórzano implicó que este libro tuviese una amplia circulación en su época, toda vez que, por una parte, había sido alabado por un jurista conocedor de la realidad americana, que indicaba que lo escrito por Reina y Maldonado llenaba un vacío relativo al derecho canónico indiano, $y$, por otra, porque la obra trata, analiza y enumera los deberes que debían cumplir los obispos americanos, especialmente los andinos. Es así como en la biblioteca del obispo de Santiago de Chile, Juan Bravo del Rivero y Correa, se encontraba un ejemplar del libro en $1653^{50}$. Asimismo, el obispo de Quito, Alonso de la Peña Montenegro, no sólo leyó esta obra, además en el manual de su autoría Itinerario para párrocos de indios ${ }^{51}$, publicado en Madrid en 1668, reeditado en 1771 y 1777, y que fue ampliamente usado en la América española, cita en numerosos pasajes Norte claro del perfecto prelado de Pedro de Reina y Maldonado.

49 Ibíd., p. 308.

${ }^{50}$ En la biblioteca del obispo de Santiago Juan Bravo del Rivero y Correa se encontraba un ejemplar del libro. Millar, René; Larraín, Paz, Notas para la historia de la cultura en el período indiano. La biblioteca del obispo de Santiago Juan Bravo del Rivero y Correa (1685-1752), en Revista Historia, 26 (1991-1992), p. 203.

51 Peña Montenegro, Alonso de la, Itinerario para párrocos de indios en que se tratan las materias más particulares tocantes a ellos para su buena administración (Madrid, Editada en la Oficina de Pedro Marín, 1771). 
Casi un siglo más tarde, José Pérez Calama ${ }^{52}$, obispo de Quito desde finales de la centuria, era un '[...] sacerdote ilustrado, renovador y progresista que trabajó con ahinco en Nueva España desde su llegada a México con el obispo Fabián y Fuero, en 1765. Hombre culto, profesor de humanidades, tuvo la idea de escribir esta obra durante su misión como visitador del obispado de Michoacán con el fin de ayuda al clero vallisoletano a arrancar vicios y plantar virtudes [... $]^{\mathrm{s} 3}$. Por lo anterior, Pérez Calama escribió Política cristiana ${ }^{54}$, utilizando Norte claro del perfecto prelado que le sirvió de guía en los diversos contenidos de su obra.

A su vez, a propósito de la censura al Manual de párrocos de Miguel de Olabarrieta $^{55}$ que realizó en 1717 el cura y rector de la catedral de los Reyes Alexo Fernando de Rojas y Acevedo, quien posteriormente fuera obispo de Santiago de Chile (1718-1723) y de La Plata (1724-1770), este indicaba: "No hallo en el cosa que desdiga a nuestra Santa fe, piedad y buenas costumbres, ni que sea contraria a la regalia de su Magestad, y buen gobierno de estos Reinos; antes si una católica instrucción de curas y sacerdotes, en que imitando al Doctor don Pedro de Reyna Maldonado Canónigo de Trujillo, que escribió el Perfecto Prelado, enseña en esta Don Miguel el Perfecto Cura, para que arreglándose su Doctrina los que lo son, conozcan la altura del ministerio, que ejercen y estado, que obtienen, siendo el cuidado de las Almas un ejercicio, que encierra grandísimo peligro, por ser el arte de las artes [...] "56 .

A su vez, el libro de Reina y Maldonado tuvo una difusión importante. Se han encontrado copias del mismo en Santiago de Chile, Michoacán, Quito y en Lima, tal como da cuenta Alexo de Rojas y Acevedo. Más aún, para el siglo XVIII se lee como una in s t r u c c i ón que forzosamente deben tener presente los prelados americanos, lo que cobra una real trascendencia en cuanto se entiende que las visitas de idolatrías responden a un deber. A su vez, esta obra seguramente circuló en el Alto Perú de la mano de Rojas y Acevedo cuando fue electo obispo de La Plata, pero también en diversos espacios de Nueva España y el Caribe, puesto que Reina y Maldonado se trasladó a dichas latitudes luego de ser elegido primero

52 Para más detalles de José Pérez Calama, ver a Brading, David, Una iglesia asediada. El obispado de Michoacán. 1749-1810 (México, Fondo de Cultura Económica, 1994).

53 Saranyana, José Ignacio (dir.); Alejos-Grau, Carmen José, Teología en América Latina. Escolástica barroca, Ilustración y preparación de la independencia (1665-1810) (Madrid, Iberoamericana. Vervuert., 2005), II/I, pp. 621 y 622.

${ }^{54}$ Pérez Calama José, Política cristiana (Asunción de Guatemala, Impreso en el Taller de Antonio Sánchez Cubillas, 1782).

${ }_{55}$ Miguel de Olabarrieta era cura y vicario de Soraya en el obispado del Cusco. Abogado de la Real Audiencia. Comisario de la Santa Cruzada en la Provincia de Aymaraez. Información dada por don Pedro de la Serna, cura rector de la iglesia de Santa Ana. Olabarrieta, Miguel de, Recuerdo de las obligaciones del ministerio apostólico en la cura de las almas. Manual moral ordenado primariamente a los señores parochos o curas de este nuevo mundo, en este reino del Perú, y de las demás Indias; según los decretos del Santo Concilio Tridentino, y del Sagrado concilio Tercero Limense, aprobado por la Santidad del Papa Sixto V; y según los demás Concilios y Sinodos, a que se refiere (Lima, 1717).

${ }^{56}$ Aprobación al Manual Moral por Alexo Fernando de Roxas y Acevedo, cura y rector de la catedral de Los Reyes, que fue Sayan en el arzobispado de Lima. Lima, mayo de 1716. Olabarrieta, Miguel de, cit. (n. 55). 
canónigo de Puebla y posteriormente obispo de Santiago de Cuba, prelatura que no llegó a ocupar debido a que murió antes de asumir la diócesis.

Norte claro del perfecto prelado es un libro destinado a ser leído especialmente por determinadas personas. Tras ello está el deseo, como se ha dicho, de Pedro de Reina y Maldonado de darse a conocer en los más importantes círculos del poder e influencias. En efecto, el canónigo de Trujillo logró suscitar la atención de las altas autoridades de la administración monárquica y eclesiástica, así como de las autoridades intelectuales -Solórzano y Pereira, por ejemplo-. Con ello, para Reina y Maldonado ya era posible postular a nuevos cargos o canonjías y, por qué no, a obispo de alguna diócesis americana. Después de todo, hacía gala de su conocimiento de las cosas de las Indias a través de sus libros, lo que era una ventaja comparativa respecto de otros muchos posibles candidatos.

\section{Obispos: FACUltades y DEBERES EN LOS ANDES}

La obra de Pedro de Reina y Maldonado cumple otro objetivo trazado por su autor: dar a conocer y explicar los diversos deberes de los obispos americanos, especialmente los relativos a los indios, entre ellos el amparo, enseñanza, cuidado y la visita de idolatrías, la que entendía como una visita diversa a la pastoral o eclesiástica, la que analiza y desarrolla en otro apartado de su libro ${ }^{57}$.

Con todo, y pese a las censuras y aceptación de las publicaciones de Reina y Maldonado, cabe preguntarnos si echar a andar toda la maquinaria de las visitas de idolatrías era una decisión optativa, o si efectivamente - de acuerdo a lo señalado por el canónigo- los obispos estaban compelidos a organizar estos tribunales itinerantes en caso de tener noticias de la existencia de prácticas contrarias a la ortodoxia.

El cuestionamiento cobra relevancia, puesto que sabemos que al tiempo de organizarse este sistema, el obispo Lobo Guerrero pretendía que fuese una política aplicable a toda la arquidiócesis limeña. Sin embargo, ello no fue posible ${ }^{58}$, y en el Sínodo de 1613 solo se regularon algunos aspectos de la institución, lo que tuvo efectos en la diócesis en cuestión. Para mediados del siglo XVII, el canónigo de la diócesis de Trujillo Pedro de Reina y Maldonado señala que efectivamente la visita de idolatrías constituye un deber episcopal. Paralelamente, el obispo de Lima Pedro de Villagómez, quien también pretendía darle un carácter continental a las visitas, dictó una carta pastoral, de amplia circulación virreinal, en la que reactualizaba el sistema normativo de las visitas de idolatrías ${ }^{59}$. Más aún, en la época en que se publican la obra de Reina y Maldonado y la Carta Pastoral de

${ }^{57}$ En efecto, Reina y Maldonado analiza la visita pastoral en el tomo I de su obra, libro III, mientras que la visita de idolatrías se encuentra en el tomo II, libro VI, observándose diferencias sustanciales entre unas y otras. Reina y MALDONADO, Pedro, cit. (n. 1), Respecto a la naturaleza jurídica de las visitas de idolatrías, ver Cordero Fernández, Macarena. Institucionalizar y desarraigar, cit. (n. 8), p. 183.

58 Para más detalles, ver Cordero Fernández, Macarena, Institucionalizar y desarraigar, cit. (n. 8), pp. 245 ss.

59 Para más detalles, ibíd., pp. 273 ss. 
Villagómez, en la diócesis de Trujillo y Charcas se reproduce en la praxis el sistema ideado en Lima a comienzos del siglo XVII, sometiéndose a proceso a los indios sospechosos de idolatrar.

Creemos, en definitiva, que las visitas de idolatrías constituyeron un deber de los obispos andinos. Así como ellas fueron una institución propia del derecho canónico local ${ }^{60}$, también se generó una serie de facultades, derechos y deberes episcopales diversos a los conocidos y regulados por la Iglesia universal. El Nuevo Mundo planteó una serie de desafíos a la Corona y a las autoridades eclesiásticas, las que debieron resolver asuntos complejos y en los que no podían esperar la autorización de la Santa Sede; de ahí que los obispos americanos contaran con nuevas atribuciones y deberes o les fueran suprimidos otros, precisamente porque la realidad que vivían era diversa.

En efecto, cuando Villagómez publicaba su carta pastoral, el canónigo de Trujillo Pedro de Reina y Maldonado -tal como lo hemos señalado-, escribió, entre otras tantas obras de su autoría, este libro de importante repercusión sobre los deberes de los obispos, con gran énfasis en aquellas obligaciones que surgían de las circunstancias distintivas y específicas de la realidad americana, donde describe y detalla, entre otras, los motivos que dan pie a las visitas de idolatrías, al señalar que: "[...] faltando los Curas a obligaciones tan precisas, y sobrándole a los indios Ministros y Maestros de la Idolatría, se deja bien entender que al poco cuidado de sus curas, pondrán el suyo, y en todas ocasiones y en todos los tiempos, les estarán repitiendo las cosas que aprendieron con la leche, y que conforme a su capacidad e inclinación y que no teniendo quien le enseñe los misterios de nuestra fe, que son tan importante a su entendimiento, cuanta ignorancia tendrán en las cosas de la religión cristiana. Y cuan enseñados y actuados estarán en la fe de su gentilidad: y mientras no se les desengañe de sus errores, por demás esta pensar que hayan de recibir la fe estos indios, aunque más le repitan y hagan repetir la doctrina cristiana: y la causa de esto, y la verdadera no es otra que el poco orden y modo de doctrinar que muchos curas han tenido [...] se contentan con que repitan algunos rezos y oraciones, algunas cosas de la religión, pero todo es superficial, porque lo repiten como papagayos, y siguen engañados por el demonio ${ }^{61}$ ".

Ante la inesquivable circunstancia de la apostasía indígena andina y la persistencia de las idolatrías, las autoridades reales y eclesiásticas limeñas plantearon y desarrollaron una solución mediante la creación de una nueva institución: las visitas de idolatrías, las que fueron reproducidas -en la práctica- en Trujillo y Charcas, proyéctandose como un $\mathrm{d}$ e b e $\mathrm{r}$ de los obispos andinos $-\mathrm{y}$, por qué no pensarlo, de los americanos-, según lo indicó Pedro de Reina y Maldonado en su obra: "[...] En donde hubiera noticias bastante que hay idolatrias, llegado al pueblo el visitador y el cura con exhortaciones, y los padres misioneros en sus sermones $y$ confesiones animarán a los indios a que se manifiesten, quitándoles el temor y empacho que se lo puede estorvar: y se les dará a entender el grave delito que ha cometido los que han adorado a las huacas, consultado hechiceros y justamente les dirá que tales

\footnotetext{
${ }^{60}$ Para más detalles, ibíd., pp.183 ss.

${ }^{61}$ Reina y Maldonado, Pedro, cit. (n. 1), II, VI, pp. 288 y 289.
} 
cosas han hecho están descomulgados, que son enemigos de Dios, y que para absolverles y sacarles del pecado en que están, es menester examinarlos a cada uno de por si, para que declaren las Huacas, y Malquis que han adorado, y las Conopas, e idolos que tienen, $y$ las ofrendas, $y$ de que son, y como especificandolo todo por sus nombres y señales, sin levantarse a si, ni a otro, testimonio, porque si lo hicieren contra si, o contra otra, o encubrieren la verdad que saben, se les castigará con rigor [...] $Y$ sin más información que la noticia, se procede a la averiguación, pues en casos de Fe, y Religión, supersticiones, e idolatrías, no se ha de tener en poco cualquier principio, porque será más culpable la pereza y descuido de los Curas en no haberlo manifestado, que la demandada diligencia del Prelado, y su visitador y menos inconveniente será prender a un denunciado Inocente, mientras no consta que lo es, que permitirle pase de largo a otro beneficio sin averiguarlo, dejando las Doctrinas sin corrección y castigo, los que están indiciados de alguna sospecha de idolatrías ${ }^{262}$.

¿Es posible, entonces, considerar la organización de estos tribunales ad hoc como un deber de los obispos andinos? ¿Por qué Pedro de Reina y Maldonado entendió la extirpación de idolatrías mediante la visita ad hoc como una exigencia para los obispos americanos?

Pues bien, debemos establecer que, etimológicamente, el vocablo obispo corresponde a inspector o superintendente, esto es, "por aquel ha de entender sobre todos los de su obispado en lo temporal e en lo espiritual; e sobre los legos en las cosas espirituales" ${ }^{33}$. Dicho de otro modo, al interior de sus diócesis los obispos eran quienes gobernaban a todos los que la integraban, y por lo mismo contaban con plenitud de poderes ${ }^{64}$, es decir, con la potestad de orden y jurisdicción. La primera, recibida directamente de los apóstoles, les permitía impartir los sacramentos, realizar todas las consagraciones, etcétera. ${ }^{65}$ "En cuanto a la segunda, los obispos tenian la potestad de jurisdicción ordinaria transmitida también por los apóstoles, con la diferencia de que la de estos últimos no se enmarcaba en determinados limites territoriales o diócesis. Dicha jurisdicción consistía en el derecho de elegir y gobernar la diócesis ${ }^{66}$, lo que conllevaba, entre otras cosas, la posibilidad de administrar justicia en vistas a la eterna salud de los fieles. Para ello se consideraba al obispo juez ordinario en asuntos eclesiásticos, tanto por la materia que conocían como por

62 Reina y Maldonado, Pedro, cit. (n. 1), II, VI, p. 333.

${ }^{63}$ Cap. Qui episcopatum 8, quaest I., dist. 93,_ley 16, tit. 5, art. 1, en Donoso, Justo, Instituciones de derecho canónico (Friburgo, Ed. Herder, 1909), p. 152. Asimismo, Murillo Velarde indica en el capítulo XXXI Del oficio del juez ordinario, 331, "el obispo sigue al arzobispo, y su nombre viene de la palabra griega, que en latín significa superintendente o vigilante C. 1. D. 2. Y comúnmente es llamado ordinario, porque ejerce la jurisdicción ordinaria, en cierto lugar o distrito, que se llama diócesis, y ciertamente, es un superior eclesiástico dotado de un especial carácter de orden, que preside al clero y al pueblo en cuanto a la cura de almas". Murillo Velarde, Pedro, Curso de derecho canónico hispano e indiano (México, Colegio de Michoacán, Facultad de Derecho UNAM, 2004), I, Libro I, pp. 397 ss.

${ }^{64}$ Conc. Trid, sess. 25 c. 4.

65 Ibíd.

${ }^{66}$ Donoso, Justo, cit. (n. 63), p. 154. 
las personas que quedaban bajo su administración ${ }^{67}$. Se entendía por juez ordinario aquel que "[...] por propio cargo y, por tanto, por su derecho, ejerce jurisdicción por razón del oficio que obtiene ${ }^{\prime 68}$.

Así, el obispo -que cuenta con jurisdicción propia- gobierna la diócesis, constituyendo una especie de "[...] sociedad perfecta, en cuanto tiene su propio e inmediato gobierno, y puede preservarse a si misma de todos los medios conducentes a la eterna salud, tales como los ministros de los sacramentos, legítima predicación de la palabra divina, las leyes y estatutos convenientes, la autoridad de juzgar" ${ }^{69}$.

Con todo, el obispo solo podía ejercer sus potestades dentro del territorio que constituía su diócesis, pudiendo proveerse de todos los medios apropiados para la obtención de la integridad de la fe, tales como nombrar los ministros de los sacramentos, predicar la palabra divina, establecer las leyes y estatutos que considerara convenientes, ejercer la autoridad de juzgar, entre otras ${ }^{70}$. "Seguidamente, la jurisdicción ordinaria de los obispos los facultaba para conocer de causas espirituales, entendidas estas no solo como las que de por sí y en su esencia producían un efecto espiritual-tales como los sacramentos para conferir la gracia espiritual y las que se encaminan por su naturaleza al culto divino y usos piadosos-, sino también como las relativas a los diezmos, beneficios eclesiásticos, preeminencias y a la salud de las almas y los pecadores ${ }^{71}$. Los obispos, por tanto, podían conocer de causas matrimoniales, de patronato o funerarias y de los delitos o crimenes, entre ellos las conductas que atentasen contra la fe" 72 .

Ahora bien, sabido es que pese a la reproducción en América del derecho canónico, del derecho castellano, de instituciones hispanas, y en general de diversos derechos y obligaciones, todos ellos fueron traducidos según las especiales circunstancias geográficas, culturales y sociales de los distintos espacios que integraban el imperio español. Esto conllevó que se provocaran resignificaciones y recreaciones de las mismas, dando lugar a nuevas instituciones, facultades o deberes reformulados ${ }^{73}$. En efecto, las visitas de idolatrías nacieron como res-

${ }^{67}$ Dougnac, Antonio, Manual de historia del derecho indiano (México, UNAM,1994), p. 299.

${ }^{68}$ Murillo Velarde, Pedro, cit. (n. 63) I, Libro 1, pp. 397; Cordero Fernández, Macarena, Institucionalizar y desarraigar, cit. (n. 8), p. 226.

${ }^{69}$ Donoso, Justo, cit. (n. 63), p. 305.

${ }^{70}$ En cuanto a las Indias, la extensión territorial o límites de las diócesis estaban determinados como consecuencia de las conquistas militares, o ya muy avanzado el período indiano, del crecimiento de la importancia económica de ciertas regiones. BARNADAS, Joseph, La Iglesia católica en Hispanoamérica colonial, en BETHELL, Leslie, Historia de América Latina (Barcelona, Ed. Crítica, 1998), II, pp. 185-207, esp. p. 190.

${ }^{71}$ Donoso, Justo, cit. (n. 63), p. 616; Murillo Velarde, Pedro, cit. (n. 62), I, Libro I. p. 405 .

${ }^{72}$ Cordero Fernández, Macarena, Institucionalizar y desarraigar, cit. (n. 8), p. 227.

${ }^{73}$ En efecto, hay una serie de facultades con que contaron los obispos indianos, precisamente por las especiales condiciones geográficas, culturales y sociales de las Indias. Al respecto Murillo Velarde indica, entre otras muchas, "En estas provincias de las Indias, a los obispos, además de lo que por derecho común tienen, suele concedérseles algunas facultades, que por lo mismo llamamos solitas [acostumbradas] cuyo tenor es el siguiente [sólo enumeraremos algunas]: 1. Facultad de conferir las órdenes extra tempora y sin guardar los intersticios, hasta el presbiterado inclusive, si ahi existiere 
puesta a la imposibilidad de aplicar la Inquisición a los indios, y como solución a la necesidad de instalar en los Andes la ortodoxia religiosa. Asimismo, algunos deberes eclesiásticos fueron reformulados, porque tal y como estaban concebidos por el derecho canónico, eran imposibles de cumplir. Pensemos en el deber de los obispos de realizar la visita ad limina ${ }^{74}$. Para el caso de los obispos de las diócesis

necesidad de sacerdotes. 2. De dispensar en cualesquiera irregularidades, excepto en aquellas que provienen de verdadera bigamia o de homicidio voluntario, y aun en estos dos casos, solamente que ahi fuera urgente la necesidad de operarios, y en lo que se refiere al homicidio voluntario, con tal que no surja escándalo por esta dispensa. 3. De dispensar sobre el defecto de edad de un año, a causa de la escasez de operarios, para que puedan ser promovidos al sacerdocio, si por otra parte son idóneos. 4. De dispensar y conmutar los votos simples en otras obras piadosas y de dispensar por causa razonable en los votos simples de castidad y de religión. 5. De absolver y de dispensar en cualquier simonía y, en la simonía real, renunciados los beneficios; y sobre los frutos malamente recibidos, añadida alguna limosna, o penitencia saludable, al arbitrio del dispensante; o también, retenidos los beneficios, si fueren parroquiales y no hubiere quienes puedan encargarse de las parroquias. 6. De dispensar en el $3^{\circ}$ y $4^{\circ}$ grado de consanguinidad $y$ de afinidad. En el simple y mixto solamente. En el $2^{\circ}, 3^{\circ}$ y $4^{\circ}$ mixtos; pero no en el $2^{\circ}$ solo, en cuanto a futuros matrimonios. En cuanto a los pretéritos también en el $2^{\circ}$ solo, con tal que de ningún modo toque al primer grado. Se incluye también la facultad de declarar legitima la prole recibida, cuando éstos casados, se convierten a la fe católica de la herejía $o$ de la infidelidad [...] 9. De dispensar en el impedimento de parentesco espiritual, excepto entre bautizante y bautizado. 10. Pero estas dispensas matrimoniales, a saber, las referidas en los anteriores números 6, 7, 8 y 9, no se concedan, sino con la cláusula: con tal que la mujer no fuere raptada, $o$ si fuere raptada, no permanezca en poder del raptor; y en la dispensa se ha de insertar el tenor de estas facultades expresando el tiempo, para el que fueren concedidas. 11. De dispensar, cuando los gentiles e infieles tienen varias mujeres, para que después de su conversión y bautismo, puedan retener a la que prefieran de ellas, si también ésta se hace fiel, a no ser que la primera quisiere convertirse [...] 15. De absolver de herejía y de apostasía de la fe y de cisma a cualesquiera, aun eclesiásticos, así seculares como regulares; pero, no a aquéllos que fueren de lugares donde ejerce el santo oficio de la inquisición a no ser que delinquieren en lugares de misiones, donde impunemente incursionan los herejes. Tampoco pueden absolver a los que judicialmente hayan abjurado, a no ser que estos hayan nacido en tierra de herejes, y, después de la abjuración judicial, desdiciéndose, hubieren caído de nuevo en la herejía; y a éstos, solamente, en el fuero de la conciencia. 16. De absolver de todos los casos reservados a la sede apostólica [...] 21. De poseer y leer, pero no de prestar a otros, libros de herejes, o de infieles, que tratan de su religión, a efecto de combatirlos, y otros igualmente prohibidos, con excepción de las obras de Carlos de Molina, de Nicolás Maquiavelo, y de los libros que tratan principal o incidentalmente de astrología judiciaria. De tal manera, sin embargo, que tales libros no se saquen de esas provincias [...] 23. De celebrar dos veces al dia, si urge la necesidad, siempre que en la primera misa no se haya tomado la ablución: una misa antes de la aurora y otra una hora después del mediodía, y aun sin ministro, a cielo abierto, o bajo techo, pero en un lugar decente, aunque el altar esté roto, o sin reliquias de santos y estén presentes herejes, cismáticos, infieles, excomulgados y de otra forma no pudiere celebrar. Pero procure no hacer uso de la predicha facultad, o dispensa de celebrar dos veces al dia, sino por causas gravisimas y muy raras veces. En lo cual cargue grandemente su conciencia. Que si pareciere conveniente aprobar la comunicación de esta misma facultad a otro sacerdote, conforme a las normas de delegación a un inferior, o bien, hacer uso de la que alguno hubiere obtenido de la santa sede, grave seriamente su conciencia para que la comunique solamente a pocos, de madura conciencia y celo, y que sean absolutamente necesarios y no para cualquier lugar, sino donde lo pida una grave necesidad y por breve tiempo, y en cada caso apruebe las causas. MURILLO Velarde, Pedro, cit. (n. 63), I, Libro. I, pp. 410. También en Donoso, Justo, cit. (n. 63), p. 355.

${ }^{74}$ Los obispos, conforme al derecho canónico, están obligados a "presentar a la Santa Sede, cada cinco años, una relación del estado de su diócesis, y junto con ella, o por lo menos cada diez años, deben presentarse personalmente ante el Papa y verificar la visita ad limina apostolorum, o 
americanas se cambiaron los plazos de ellas, e incluso se permitió que se enviaran representantes ante la Santa Sede para dar cuenta de la gestión.

Así pues, reiteramos el planteamiento en orden a establecer si los obispos andinos tuvieron el deber de extirpar idolatrías mediante la visita de idolatrías, que como tal constituía un tribunal itinerante. La pregunta no es retórica, y cobra importancia para comprender la política eclesiástica andina que se aplicó en los diversos espacios que conformaron el virreinato peruano durante los siglos XVII y XVIII. Más aún porque dentro de los deberes de los obispos a nivel universal estaba el de mantener a sus diócesis libres de herejías o de interpretaciones erradas de la doctrina, lo que no implicaba necesariamente que el prelado debía activar la visita de idolatrías o realizar inquisición episcopal ${ }^{75}$, puesto que era suficiente con la destrucción de las prácticas que la Iglesia entendía como alejadas de la ortodoxia.

Entonces, si es que los obispos estaban obligados a organizar las visitas de idolatrías, no hacerlo significaba incumplir, por una parte, la obligación de conservar la fe libre de herejías y, por la otra, la de organizar el sistema represor. Una situación como esta eventualmente podía acarrear recriminaciones e incluso ser constitutiva de faltas que podían afectar la promoción de un obispo sufragáneo en la carrera eclesiástica del imperio español ${ }^{76}$. Incluso ser acusado de pereza y descuido como lo indica el propio Reina y Maldonado ${ }^{77}$.

De modo que los obispos, conforme al derecho, debían cumplir con su deber de mantener la ortodoxia religiosa en su diócesis. La forma de hacerlo podía variar de un espacio a otro, según la gravedad y la identidad de los involucrados, pudiendo elegir, entre otras, la vía judicial para ello.

Más aún, porque desde antiguo se entendió que la forma que tenían los obispos para poder saber si se estaba ante una idolatría era conociéndola y para ello se hacía forzoso visitar los espacios sospechosos de prácticas heterodoxas, las que serían juzgadas por el prelado o visitador en caso de probarse en la: "[...] visita, y para que cuando en ella se oyere delaciones y confesiones de los indios viejos, hechiceros $u$ otros semejantes, se les pueda preguntar y entenderse con ellos, para corregirles y enmendarles, tratando los misterios de nuestra fe, reprobando y deshaciendo

sea, a las basílicas de San Pedro en el Vaticano, y San Pablo extramuros". VAlenzuela Valderrama Héctor, Manual de derecho canónico (Santiago, Universitaria, 1963), p. 90.

${ }^{75}$ Los arzobispos y obispos tienen entre sus facultades ordinarias la de inquirir; por tanto, de tener noticias de la existencia de prácticas alejadas de la unidad de la fe. Podían iniciar proceso inquisitorial en contra del sospechoso. Más aún, "El crimen de herejía es meramente eclesiástico, y por lo mismo su conocimiento pertenece solamente a los jueces eclesiásticos, cap. 9. h. t. cap. 18. eod. in 6. L. 2. tit. 26. p. 7. et ibid. Gregorio López L. 1. tit. 3. lib. 8. R. C. ahi: Y este tal después que por el Juez Eclesiástico fuere condenado por Herege. También, lo nota ibid. Acevedo n. 116. Los jueces ordinarios en el crimen de herejía son: 1. El Pontifice. 2. El legado a latere; arg. capit. 12. h. t. in 6. Conforme a la costumbre, sin embargo el Legado no interviene, sin especial comisión del Pontifice, o del supremo tribunal de la Inquisición. 3. El obispo respecto de sus diocesanos, Cl. 1. J. 1. h. t., aunque estos sean exentos: porque entonces procede como delegado del Papa, cap. 9. h. t. 4 [...]”. Murillo Velarde, Pedro, cit. (n. 63), IV, Libro V, p. 75.

${ }^{76}$ EnRíquez, Lucrecia, De colonial a nacional: la carrera eclesiástica del clero secular chileno entre 1650 y 1810 (México, Instituto Panamericano de Geografía e Historia, 2006).

77 Reina y Maldonado, Pedro, cit. (n. 1), II, VI, p. 333. 
los errores que tiene contrarios, declarándoles qua sin fundamento, son sus idolatrías, y ceremonias, y lo que sus antepasados les enseñaron, con lo mas en particular por sus mismas declaraciones podrá sacar y advertir el Prelado, que por su dirección vera lo que en las visitas convendrá preguntar, aunque lo más común y general en estos tiempos, es lo que se apunta, pues el mismo almacigo de idolatria, y familia de supersticiones que el demonio en las tres partes del mundo Africa, Europa, y Asia, plantó [...]"'8.

Así, es necesario distinguir:

1. Deberes del obispo: uno de ellos, mantener la fe libre de herejías.

2. Facultades de los obispos de carácter ordinario: las que le permiten inquirir a la población heterodoxa o que realiza prácticas que pueden dar pábulo a una herejía. Es lo que llamamos inquisición episcopal. No obstante, los obispos en el Nuevo Mundo no la usarán desde la instalación del Santo Oficio en América en 1570 .

3. El Santo Oficio no tuvo jurisdicción sobre los indígenas durante todo el Antiguo Régimen. Así, este importante grupo colonial quedó excluido del control inquisitorial, pese a que este tuvo su reproducción institucional en América.

4. Los obispos del espacio andino, al verse con el tamaño problema de la pervivencia de las idolatrías, idearon junto a otras autoridades eclesiásticas y reales un plan de acción, el que se concretó en la institución canónica indiana denominada visitas de idolatrías. Este sistema se basaba en el procedimiento inquisitivo, pero difería del oficial, puesto que aunque era la reproducción de un sistema de control de la religiosidad europea, hubo de traducirse a las especificidades andinas, lo que dio lugar a un sistema original, el que se activaba solo si había noticias de la existencia de un foco idolátrico.

5. Cada vez que se tenía noticias de la existencia de un foco idolátrico entre los indios supuestamente convertidos y bautizados, los obispos americanos -a lo menos los sufragáneos de Lima- estaban obligados a organizar las visitas de idolatrías, pues así estaba contemplado en la legislación originada en América, la que contaba con todas las autorizaciones que exigían los parámetros jurídicos de la época.

6. De no organizarse las visitas, los obispos caían en el incumplimiento de varias obligaciones, entre ellas la de conservar la fe católica intacta entre los indios, reprimir las idolatrías y reevangelizar a los idólatras, y sujetos ser considerados perezosos y descuidados.

Así pues, Reina y Maldonado, al escribir Norte claro del perfecto prelado, dio cuenta de la existencia de instituciones y deberes distintos a los contemplados por el derecho canónico universal. Para ello describió en su obra el deber episcopal: de realizar la visita de idolatrías dirigida a suprimir la influencia de los indígenas apóstatas. Ello importó un reconocimiento de la existencia de obligaciones obispales que empezaban a asumirse como distintas de las europeas -que eran las universales- y propias del contexto en el que surgían. En efecto, la historia del derecho y las instituciones suelen presentar todas las nuevas instituciones a partir de la legislación monárquica o de las disposiciones del poder temporal. No

${ }^{78}$ Reina y Maldonado, Pedro, cit. (n. 1), II, VI, p. 289. 
obstante, como se ha visto, también hubo importantes variaciones, creaciones y reformulaciones de las instituciones, derechos y deberes de los obispos y párrocos en América. En pocas palabras, el derecho canónico también sufrió recreaciones y t r a d u c ci o n es al contexto especial en que se aplicaba.

Al registrar este nuevo deber de los obispos americanos, Pedro de Reina y Maldonado -con la censura de figuras como Solórzano- plasmó, de alguna manera, las cocreaciones institucionales de la Iglesia en el espacio andino. Incluso más, un siglo después el jesuita Pedro Murillo Velarde enumerará en su Curso de derecho canónico indiano una serie de exigencias que les corresponde específicamente a los obispos en las Indias. En buenas cuentas, diversas voces en espacios tan disímiles como Manila, Trujillo o Madrid se levantaron para indicar que, al igual que las instituciones castellanas, las eclesiásticas cambiaban para asegurar la paz y la conversión de las almas.

\section{Algunas consideraciones finales}

La obra de Pedro de Reina y Maldonado es significativa, puesto que permite comprobar cómo se aplicaron en la América andina instituciones distintas a las reguladas por el derecho canónico universal, el que ciertamente se reprodujo en el Nuevo Mundo. Sin embargo, la realidad en este continente presentó una serie de desafíos, conflictos y problemas que las altas autoridades debían resolver. Las más de las veces no podían esperar las soluciones propuestas por la Santa Sede o desde el Consejo de Indias. Sobre la base de las facultades que tenían los obispos en su calidad de tales, pudieron normar, regular y dar origen a nuevas instituciones, deberes y facultades; en definitiva, nuevos espacios normativos. Tal como se ha indicado en esta investigación, el obispo y sus diócesis debían constituir una sociedad perfecta, y por ello contaban con amplias atribuciones para regular situaciones que escapaban de lo pensado y querido para y desde Europa.

Es más, tal como se señaló al comienzo, la pervivencia de las idolatrías fue interpretada por teólogos, juristas, doctrineros, virreyes y otras autoridades como el equivalente a una marea de apostasía, que era inaceptable, pues había mucho en juego: la posibilidad de conquistar y colonizar el Nuevo Mundo solo podía realizarse en cuanto la monarquía apoyada por la Iglesia convirtiera miles de almas. Pero aún más, estaba en juego la s a lv a c i ó n de millones de almas, principal valor jurídico, social y cultural del Antiguo Régimen.

En tal estado de las cosas, al saberse o tener noticias de la existencia de un foco heterodoxo, el obispo tenía el deber -y no la simple facultad- de organizar las visitas de idolatrías. Se trata, evidentemente, de un deber que no está regulado en el derecho e instituciones reproducidas por la cultura dominante. Ante la diversidad de problemas y la diferencia propias de la realidad peruana, los obispos, autoridades virreinales y juristas resignificaron y cocrearon deberes e instituciones para brindarles solución a los problemas propios de la realidad andina

Más aún, el canónigo de Trujillo Pedro de Reina y Maldonado contempló en su libro Norte claro del perfecto prelado el deber de realizar las visitas de idolatrías en el libro VI, tomo II, mientras que la visita pastoral la presenta en el libro III. 
De haberse tratado de una misma institución y de un mismo deber, es obvio que el canónigo en comento no iba a presentarlas -como lo hizo- como distintas y a regularlas en diversos libros. En efecto, el sacerdote, contemporáneo a los acontecimientos descritos en Lima, entendió que se trataba de dos instituciones distintas, en las cuales el obispo cumplía deberes de diversa índole, pues cada especie de visita se organizaba, financiaba y utilizaba para finalidades específicas, que contaban además con instrucciones y regulaciones particulares.

Lo interesante y novedoso es que esta distinción la hace un sacerdote que vivió en el virreinato del Perú y que, por lo tanto, debió saber que en tiempos de Lobo Guerrero se consideró que las visitas de idolatrías eran una posible solución a los problemas que afectaban a las zonas rurales de los Andes, y que ellas fueron revitalizadas mediante la carta pastoral de Pedro de Villagómez en 1649. Es más, en la época en que se publicó su obra, cuyo contenido tuvo por objeto establecer cuáles eran los deberes de los obispos, las visitas de idolatrías eran ya una institución propia del derecho canónico indiano, cuya naturaleza jurídica difería de la visita pastoral. De ahí que, reiteramos, el sacerdote Pedro de Reina y Maldonado, al enumerar y señalar los deberes, derechos, atribuciones, funciones y facultades de los obispos, indique, además, la existencia de estas dos instituciones en apartados diversos, las cuales podía y debía utilizar según fuese el caso. No cabe más que establecer que se trata de un deber obispal diverso, de naturaleza jurídica, finalidades y procederes distintos y determinados, cuyo origen además responde a objetivos disímiles.

En cuanto a Reina y Maldonado, su autoagenciamiento fue todo un éxito. Contaba con varias obras escritas y publicadas en Madrid. Tenía buenas relaciones con las autoridades virreinales y eclesiásticas del Perú; había sido eficiente en los cargos que le correspondió ocupar, y seguramente la censura realizada a su obra magna por Solórzano Pereira, quien reconocía en el canónigo su alter ego en materias relativas al derecho canónico, logró la promoción en su propia carrera eclesiástica. Así, al dar pruebas fehacientes de su erudición, conocedor de las cosas de las Indias y de ser un buen cristiano, y más importante aún, entender y saber cómo y qué debía hacer un obispo en América, tuvo noticia en vida de que había sido nombrado obispo en Cuba.

\section{BiBLIOGRAFÍA}

Fuentes

Acosta, Joseph de, De procuranda indorum salute (Madrid, Consejo Superior de Investigaciones Científicas, 1984), 2 vols.

AlbORNOZ, Cristóbal, Instrucción para descubrir todas las guacas del Perú y sus camayos y haciendas, en Urbano, Henrique; Duviols, Pierre (ed.), Molina y Albornoz. Fábula $y$ mito de los Incas (Madrid, Historia 18, 1989).

Arriaga, Pablo de, Extirpación de la idolatría en el Perú. Estudio preliminar y notas de Urbano, Henrique (Cusco, Centro de Estudios Regionales Andinos Bartolomé de las Casas, 1999). 
De censibus, exactionibus et procurationibus. Información Pedro de Reina y Maldonado. 1647. Archivo General de Indias, Lima, 240, No 6.

Los Sacro Santos Ecuménicos Concilios de Trento y Vaticano. Traducción del presbítero Anastasio Machuca Diez (Madrid, Librería católica de Gregorio del Amo, 1903). MedinA, José Toribio, Biblioteca Hispanoamericana (1493-1810) (Santiago, Imprenta del Autor, 1898), II.

Murillo Velarde, Pedro, Curso de derecho canónico hispano e indiano (México, Colegio de Michoacán, Facultad de Derecho UNAM, 2004).

Nueva Ordenanza para el Consejo, Felipe II, El Pardo, 24 de Septiembre de 1571. Cap. 5, en Anuarios de Estudios Americanos, 14 (1957).

Olabarrieta Medrano, Miguel de, Recuerdo de las obligaciones del ministerio apostólico en la cura de las almas. Manual moral ordenado primariamente a los señores parochos o curas de este nuevo mundo, en este reino del Perú, y de las demás Indias; según los decretos del Santo Concilio Tridentino, y del Sagrado concilio Tercero Limense, aprobado por la Santidad del Papa Sixto V; y según los demás Concilios y Sinodos, a que se refiere (Lima, 1717).

Peña Montenegro, Alonso de la, Itinerario para párrocos de indios en que se tratan las materias más particulares tocantes a ellos para su buena administración (Madrid, Editada en la Oficina de Pedro Marín, 1771).

Pérez Calama, José, Política cristiana. (Asunción de Guatemala, Impreso en el Taller de Antonio Sánchez Cubillas, 1782).

Poma de Ayala, Felipe Guaman, Nueva crónica y buen gobierno. Traducción, prólogo, notas y cronología, Franklin Pease (Caracas, Biblioteca Ayacucho, 1980).

Reina y Maldonado, Pedro. Norte claro del perfecto prelado en su pastoral de gobierno. Tratase en el de la economía y policía domestica de su casa y acertada elección de sus ministros con disposición de las visitas de su catedral e iglesias (Madrid, Melchor Sánchez, 1653).

Sínodo de Lima de 1613, celebrado durante el obispado de Bartolomé Lobo Guerrero VILlagómez, Pedro de, Carta pastoral de exhortación e instrucción acerca de las idolatrías de los indios del arzobispado de Lima. 1649.

Literatura

Aguirre, Carlos, Agentes de su propia libertad (Lima, Pontificia Universidad Católica del Perú, 1995).

BARNADAS, Joseph, La Iglesia católica en Hispanoamérica colonial, en BETHELL, Leslie, Historia de América Latina (Barcelona. Ed. Crítica, 1998), II.

BRADING, David, Una iglesia asediada. El obispado de Michoacán. 1749-1810 (México, Fondo de Cultura Económica, 1994).

Castro, Victoria, Un proceso de extirpación de idolatrías en Atacama, siglo XVII, en Ramos, Urbano, Catolicismo y extirpación de idolatrías. Siglos XVI-XVIII (Cusco, Centro de Estudios Regionales Andinos Bartolomé de las Casas. Cuadernos para la evangelización en América Latina. № 5, 1993), pp. 347-366.

Castro, Victoria, De idolos y santos. Evangelización y religión andina en los Andes del sur (Santiago, Fondo de Publicaciones Americanistas Universidad de Chile. Centro de Investigaciones Diego Barros Arana, 2009).

COMADRÁN RUIZ, Jorge, Los sacerdotes criollos y las prelaturas indianas durante el periodo indiano, en Missionalica Hispana. Hispana Sacra, 42/85 (1990), pp. 213-249. 
Cordero Fernández, Macarena, Institucionalizar y desarraigar. Las visitas de idolatrías en la diócesis de Lima, siglo XVII (Lima, Instituto Riva Agüero, Pontificia Universidad Católica de Lima, Universidad Adolfo Ibáñez, 2016).

-- Precariedad del proyecto disciplinador de la Corona e Iglesia en el siglo XVIII: las doctrinas periféricas de la diócesis de Santiago de Chile, en GAUnE Rafael; UndurRaGa, V. Formas de Control y disciplinamiento. Chile, América y Europa, siglos XVI-XIX (Santiago de Chile, Uqbar Editores, 2015), pp. 143-166.

-- Inquisición en Chile y control social, en SÁnCHEZ, Marcial (comp.), Historia de la Iglesia en Chile (Santiago, Ed. Universitaria, 2010), II, pp. 163-193.

Donoso, Justo, Instituciones de derecho canónico (Friburgo, Ed. Herder, 1909).

Dougnac, Antonio, Manual de historia del derecho indiano (México, UNAM, 1994).

Duve, Thomas, Los privilegios de los indios ¿derecho local?, en ToRres AguILAR, Manuel (coord.), Actas del XV Congreso del Instituto Internacional de Historia del Derecho Indiano. Córdoba, del 19-24 de septiembre 2005 (Córdoba, Diputación de Córdoba, Universidad de Córdoba), I, pp. 111-130.

Duviols, Pierre, La lutte contre les religions autochtones dans le Pérou colonial (Lima, Travaux de L'Institut Français d'Etudes Andines. L'Institut Français d'Etudes Andines, 1971).

-- Albornoz y el espacio ritual andino prehispánico, en Revista Andina, 2/1 (Cusco, 1984).

-- Cultura andina y represión: procesos y visitas de idolatrias, Cajatambo siglo XVII (Cusco, Centro de Estudios Rurales Andinos Bartolomé de las Casas, 1986).

-- Procesos y visitas de idolatría. Cajatambo siglo XVII (Lima, Pontificia Universidad Católica del Perú, 2003).

ENRíQuez, Lucrecia, De colonial a nacional: la carrera eclesiástica del clero secular chileno entre 1650 y 1810 (México, Instituto Panamericano de Geografía e Historia, 2006).

Estenssoro Fuchs, Juan Carlos, Descubriendo los poderes de la palabra: funciones de la prédica en la evangelización, en Ramos, Gabriela, La venida del Reino (Cusco, Centro de Estudios Regionales Andinos Bartolomé de las Casas, 1994), pp. 75-101.

García Cabrera, Juan Carlos, Ofensas contra Dios (Cusco, Centro de Estudios Bartolomé de las Casas, 1994).

GAREIS, Iris, La metamorfosis de los dioses: cambio cultural en las sociedades andinas, en Anthropologica, 9 (Lima, 2012), pp. 245-257.

GreenleAf, Richard, La Inquisición en Nueva España. Siglo XVI (México, Fondo de Cultura Económica, 1985).

-- Zumárraga y la Inquisición mexicana, 1536-1543 (México, Fondo de Cultura Económica, 1985.

Griffiths, Nicholas, La cruz y la serpiente (Lima, Pontificia Universidad Católica del Perú, 1998).

Guibovich, Pedro, Visitas eclesiásticas y extirpación de la idolatría en la diócesis de Lima en la segunda mitad del siglo XVII, en ZABALLA (coord.), Los indios, el derecho canónico y la justicia eclesiástica en la América virreinal, en Iberoamericana Vervuert (2011), pp. 177-209.

Guibovich, Pedro y Wuffarden, Luis Eduardo, Sociedad y gobierno episcopal. Las visitas del obispo Manuel de Mollinedo y Angulo 1674-1687 (Lima, Instituto Riva Agüero, Instituto Francés de Estudios Andinos, 2008).

Hidalgo, Jorge, Historia andina en Chile (Santiago, Editorial Universitaria, 2004).

-- Redes Eclesiásticas, procesos de extirpación de idolatrías y cultos andinos coloniales en Atacama. Siglos XVII y XVIII, en Estudios Atacameños, 42 (2011), pp. 113-152. 
LARCO, Laura, Más allá de los encantos. Documentos históricos y etnografía contemporánea sobre extirpación de idolatrías en Trujillo. Siglos XVIII-XX. (Lima, Instituto Francés de Estudios Andinos. Fondo editorial Universidad de San Marcos, 2008).

LE BRAS, George, Les origines canoniques di droit administratif, en L'evolution du droit public. Études offertes a Achille mestre (París, Sirey, 1956).

Millar, René y Larraín, Paz, Notas para la historia de la cultura en el periodo indiano. La biblioteca del obispo de Santiago Juan Bravo del Rivero y Correa (1685-1752), en Revista Historia, 26 (Santiago, 1991-1992).

Mills, Kenneth, Idolatry and its enemies. Colonial Andean religion and extirpation, 1640-1750 (New Jersey, Universidad de Princeton, 1997).

Pardo Sandoval, Teresa, Un impreso peruano, en Boletín Instituto Riva Agüero (Lima, 1988), pp. 155-162.

Regalado De Hurtado, Liliana, Religión y evangelización en Vilcabamba 1572-1602 (Lima, Pontificia Universidad Católica del Perú, 1992).

Saranyana, José Ignacio (dir.); Alejos-Grau, Carmen José, Teología en América Latina. Escolástica barroca, Ilustración y preparación de la independencia (1665-1810) (Madrid, Iberoamericana. Verbereut., 2005) Vol. II/I.

Subirats, Eduardo, El continente vacio (México, Editorial Siglo XXI, 1994).

Thompson, E.P., The Making of the English Working Class (New York, Vintage Books, 1963).

Traslosheros, Jorge, Armonía de voluntades. Potestades eclesiásticas y secular en la Nueva España del siglo XVII, a propósito de San Miguel el Grande, en Iberoamericana, Nueva Época, 1/3 (2001), pp. 41-60.

Valenzuela Valderrama, Héctor, Manual de derecho canónico (Santiago, Universitaria, 1963).

Vargas Ugarte, Rubén, Historia de la Iglesia en el Perú (Burgos, Imprenta de Aldocoe, 1959), III. 